\title{
Building an ambient room to foster the teaching/learning of anatomy and physiology of the human digestive system
}

\section{A construção de uma sala ambiente como fator motivador e facilitador do ensino/aprendizagem de anatomia e fisiologia do aparelho digestivo humano}

\author{
${ }^{1}$ Carlos Alberto Sanches Pereira sanches68@gmail.com \\ ${ }^{1}$ Marcelo Ribeiro de Almeida Guedes \\ ${ }^{1}$ Denise Celeste Godoy de Andrade Rodrigues \\ ${ }^{1}$ Gabriela Girão de Albuquerque \\ ${ }^{1}$ Maria da Conceição Vinciprova Fonseca
}

\begin{abstract}
The current teaching model has been characterized by activities distant from the student's reality and mainly based on memorization. Since it is assumed that unconventional teaching strategies may foster the knowledge of the syllabus contents, this paper aims to present the construction of an ambient room simulating the human digestive system to provide high school students an experience of its physiological processes. The room was built in a government school with different materials, such as nonwoven fabric, PVC pipes, mortar and PET bottles. Visiting the ambient room, monitored by their teacher, the students were able to simulate the experience of each stage of the digestive process, allowing one to believe that the ambient room can be an effective playful approach activity, enabling students to construct meaningful learning on subjects which otherwise they may see as too theoretical and of difficult comprehension.
\end{abstract}

Keywords: teaching of the digestive system, playful approach activity, ambient room, education, learning.

\section{RESUMO}

O ensino atual tem-se caracterizado por atividades distantes da realidade do aluno e baseadas, principalmente, em memorização. Uma vez que se acredita que estratégias não-convencionais de ensino podem facilitar e reforçar o conhecimento definido na matriz curricular, este trabalho objetiva apresentar a construção de uma sala-ambiente que simula sistema digestório humano, visando proporcionar a estudantes de segundo grau uma experiência de seus processos fisiológicos. A sala foi construída em uma escola pública com a utilização de materiais diversos, tais como tubos de PVC, garrafas PET e argamassa. Ao visitar a sala-ambiente, monitorados pelo professor, os alunos puderam simular a experiência de cada estágio do processo digestório, o que permite afirmar que a sala-ambiente pode ser uma atividade lúdica favorecedora da aprendizagem, possibilitando aos alunos a construção de conhecimento significativo em questões que, de outro modo, podem ser vistas como altamente teóricas e de difícil compreensão.

Palavras-chave: ensino do sistema digestório, atividade lúdica, sala-ambiente, educação, aprendizado.

1 University Centre of Volta Redonda, Rio de Janeiro - Master's Degree in Health and Environmental Sciences Education. 


\section{INTRODUCTION}

Much has been said about education in Brazil in the last decades, but the fact is that it has been based on models used in other countries, particularly from Europe, far away from the national reality and using the "topdown” format without worrying about the population needs and context (MARTINS, 2013).

Even with so many innovative tools provided by computer technology, the teacher still faces difficulties in the classroom, especially regarding students' motivation. A hands-on approach may optimize learning to the largest possible number of students, leading to good results.

Certain issues are complex for students because of their need to associate knowledge with their daily lives, which is often not obvious. In most cases teachers fail to develop activities that can provide this interaction, and public institutions hardly ever dispose of a space for students to experience the taught content.

The interrelationship between classroom and everyday life can enable students to understand the purpose of given content and would make concepts, previously only memorized, become now part of their reality. Busnardo and Lopes (2010) state that "the use of contents that are closer to the student's daily life is generally related to the idea of motivation as a facilitator of the learning process and of some possibility of intervention in the world in which we live."

According to Becker (1993), there are still those who believe the myth of knowledge transfer: teachers transmit a content to students, who only have to submit to the teacher's rules until they have in their minds what the teacher intended to give them.

Thus the current education model has been characterized by activities distanced from the students' reality and mainly based on memorization (BECKER, 1993; MAGALHÃES, 2011), leading to failure in the understanding of the phenomena treated for lack of experiences. Without appropriate resources teachers end up illustrating their lectures only with schemas or textbook pictures, depriving students of a more practical contact with the matter being treated, which would put them in a closer perspective to its reality.

The teaching of Human Anatomy and Physiology has highlighted these problems, since it requires students to manipulate and identify the organ's location and understand the physiological processes in which they are involved.

Undergraduates' reports show classes on human digestive system anatomy and physiology taught almost exclusively in an expository and memorization centred fashion, relying heavily on textbooks which, despite the problems presented (MEGID, 2003), are still used as main updating source.

Professional education is also a point of difficulty, since, according to Zancul (2011), there is a noticeable lag in biological sciences undergraduate courses regarding the training of the future teachers. Anatomy and Physiology are taught in their technical-scientific basis, but it fails to approximate the processes to the students' reality. Classes are still marked by fragmented and abstruse information, making it hard for students to develop scientific concepts, understand the main ideas and bridge the gap that prevents them from incorporating the knowledge to their everyday experiences (GONZALES, 2006). Natural sciences are perceived as a jumble of laws and information with little practical sense (DE MEIS, 2002).

Starcciarini (1999) has verified that the use of unconventional teaching strategies, such as experience simulation, provides better assimilation of contents, as students become more motivated while they interact with one another. 
According to Vygotsky (2007), motivation is a key factor for the success of learning and the acquisition of new skills, and playful activities provide structures that underpin changes in needs and consciousness.

The digestive system ambient room is a playful resource, or "activities that involve fun, joy" (ROSAMILHA, 1979), and offers an experience of the digestive process, helping knowledge construction through observation of the simulations of its structures, enzymes and molecules.

Teaching can cover activities which transcend the classroom boundaries. It involves individuals that can be influenced by factors that will contribute - or not - to the creation of learning opportunities (BRAGANÇA et al., 2012).

According to Toscani et al. (2007) and Fontoura (2003; 2004), the playful atmosphere created by building an ambient room promotes learning in a more meaningful way, providing a space where students can test their knowledge and formulate hypotheses, motivated by the proposed activity itself, thus relating such concepts to their cognitive structure (MOREIRA, 2010).

Miranda (2001) and Contin (2008) state that playful processes in teaching may foster imagination, curiosity and learning itself in a joyful and effective way, developing skills as cognition, affection, socialization, motivation and creativity.

The building of an ambient room is a playful activity in which students experience classroom contents while interacting with each other and the teacher, in a socio-interactionism approach that adds efficiency to the teaching-learning process (NEVES, 2006). Vygotsky claims that learning is neither a mere acquisition of information nor does it happen from a simple association of ideas stored in memory, but it is an internal, active and interpersonal process which takes into consideration what is from within the individual and also the changes and implications carried out by the environment (NUNES, 2011).

The use of an ambient room can also provide meaningful learning, which happens when new information acquires meaning through a kind of anchoring in relevant aspects of the individuals' concepts, ideas and propositions existing in their knowledge structure with determined degree of clarity, stability and differentiation (MOREIRA, 2013).

Meaningful learning also develops the ability to transfer knowledge to its possible use in a context different than that in which it was noted (TAVARES, 2008).

The present study aims to describe the building of an ambient room to provide high-school students with the experiences of the physiological processes of the human digestive system.

\section{METHODOLOGY}

For the construction of the ambient room, the space of a classroom was made available in the State School Vila Maria, in Barra Mansa, RJ. It was part of a project supported by the Carlos Chagas Filho Foundation for Research Support of the State of Rio de Janeiro (FAPERJ).

The following materials were used: 500 PET bottles (2 L), 5 milk cartons, newspaper sheets (all recycled material), $300 \mathrm{~m}$ rigid plastic hose, $360 \mathrm{~m}$ 1/2 inch PVC pipes, $20 \mathrm{~kg}$ mortar, $10 \mathrm{~m}$ orange foam, EVA (6 white sheets, 4 pink sheets, 8 red sheets), $300 \mathrm{~m}$ of nonwoven fabric (100 m pink and $200 \mathrm{~m}$ brown), Colorjet paint (8 cans of brown, 5 red, 5 pink and 5 purple), $60 \mathrm{~m}$ dual light wire, 20 colorless light bulbs, 20 nozzles, 2 styli, Styrofoam balls ( 150 of $35 \mathrm{~mm}, 100$ of $50 \mathrm{~mm}, 100$ of $75 \mathrm{~mm}$ and 7 polystyrene balls of $200 \mathrm{~mm}$ ), 18 gouache 
pots ( 3 yellow, 3 blue, 3 red, 3 brown and 3 green), 2 pairs of scissors, 2 hot glue guns, 1 roll of string, 1 pair of pliers, 1 screwdriver, 3 rolls of cellophane, $10 \mathrm{~m}$ elastic band, 10 bags of bamboo barbecue skewers, 1 bucket, 5 paint brushes, 2 staplers, 8 rolls of duct tape, 1 roll of nylon string, 1 roll of electrical tape, 100 packs of instant glue, 2000 cable ties, 100 sticks of hot glue, 2 boxes of staples, 1 large tube of Styrofoam glue.

First the dimensions of tunnels and their paths were drawn on the floor so that the mouth, esophagus, stomach, small intestine and large intestine could be assembled in their simulated size.

Next was the assembly of support pillars for the tunnels. PVC tubes ( $1 \frac{1}{2}$ inch) were cut into 2 meter-long sticks. Plastic bottles (2 liter Coca-Cola ${ }^{\circledR}$ brand, so they were all the same size) cut in half were used. Their bottom halves were filled with mortar (as indicated by the manufacturer) and the top halves were placed on the mortar-filled base, in an inverted position. Then, the PVC pipe and more mortar were placed (Figure 1).

Six types of molecules were prepared: water, hydrochloric acid, carbohydrates, proteins, lipids and enzymes (Figure 2), with the aid of Styrofoam balls and toothpicks.

For the manufacturing of the water molecules, two balls of $35 \mathrm{~mm}$ were used, representing hydrogen atoms (left blank) and one of $50 \mathrm{~mm}$, representing the oxygen atom, painted red gouache. They were joined by wooden toothpicks, which represented covalent bonds in their molecular geometry. For hydrochloric acid a ball of $35 \mathrm{~mm}$ was used, representing the hydrogen atom (left blank) and a $50 \mathrm{~mm}$ ball representing the chlorine atom, painted green, held together by wooden toothpicks representing the ionic bond in their molecular geometry. The carbohydrate molecules were prepared using five $35 \mathrm{~mm}$ balls painted blue joined in a wooden toothpick. For the protein molecules five $75 \mathrm{~mm}$ balls were used, joined by wooden toothpicks and painted in various colors.

Lipids were assembled using six $50 \mathrm{~mm}$ balls painted red (Figure 2 and 3). To symbolize the enzymes, 6 balls of 200 mm painted yellow were used and trimmed to resemble a "Pac-Man" (Figure 3).

The water molecules and hydrochloric acid atoms were painted according to their representation schemes used in molecular chemistry (Lima 1999). For carbohydrates, proteins, lipids and enzymes, random colors were used in a way that differentiated them, so that the students would observe a determined macromolecule metabolism.

With PET bottles cut $17 \mathrm{~cm}$ from their base, the bacilli bacteria were fabricated by joining two lower parts, stuck together with adhesive tape (Figure 4). The coccoid bacteria were made with crumpled newspaper, secured with duct tape, forming balls.

The bifid bacteria (bifidobacteria) was constructed joining two tops of plastic bottles in a lower bottle half with the help of tape, in order to show the benefits they cause to intestinal colonization. Bacilli were painted red and purple colorjet, coccus pink and purple and bifid were painted purple (Figure 5). The colors symbolized the cell wall characteristic of these bacteria by Gram stain, simulating a variety of intestinal microbiota.

Rigid hose cut into $1.5 \mathrm{~m}$ pieces was used for the tunnel, fixed at two pillars with the aid of cable ties. After the arches were made, they were set in their places giving the tunnels delimitation in the room. After that the bows were glued to the floor with instant glue (super-bonder) (Figure 6), in order to give greater steadiness to the tunnels when they were coated with nonwoven fabric. The arches for the stomach delimitation were higher, made with $2 \mathrm{~m}, 2.5 \mathrm{~m}$ and $3 \mathrm{~m}$ rigid hose, so as to give a larger dimension to the stomach tunnel.

For electrical installation, 60 meters of double wire were used, attached on the arches by plastic cable ties throughout the tunnel length. At certain points nozzles were installed with the aid of stylus, for stripping wires, and electrical tape, to isolate the nozzle joints with wire. The lamps used were painted pink (for tunnels of the 
esophagus and stomach) and brown (for tunnels of the small and large intestine) colorjet (Figure 7). It is important to note that the nozzles threads were masked with tape before being painted.

The tunnels were coated in pink and brown nonwoven fabric - pink for the mouth, esophagus and stomach tunnel, and brown to cover the small and large intestine tunnels. The nonwoven fabric was stuck to the arches by cable ties and the left clamp was cut to guarantee the tunnel aesthetics (Figure 8). Cuts were made on the nonwoven fabric of the tunnel ceiling so that the bulbs could get into the tunnels.

Cellophane was used to simulate the stomach mucus aiming to represent the stomach protective effect against hydrochloric acid. For that purpose, the entire length of the stomach was coated in cellophane, fixed with the aid of hot melt glue and transparent tape (Figure 9).

The molecules were distributed throughout the tunnel so that the digestive process was the distribution guide. Protein, lipids, carbohydrates and water molecules were fixed in the mouth. Still in the mouth an enzyme was hung with a carbohydrate glued to it, so that salivary amylase could be simulated (Figure 10). Proteins, lipids, carbohydrates, water and some broken carbohydrates were placed in the esophagus, showing the digestive process performed in the mouth by salivary amylase action. In the stomach proteins, lipids, carbohydrates (whole and broken), water, hydrochloric acid and two enzymes, with proteins bonded to them simulating the action of pepsin in the stomach, were distributed. In the first portion of the small intestine three enzymes (one with a carbohydrate bonded to it, one with another, and a protein with a lipid) were placed, besides protein molecules, lipids, carbohydrates and water. In other portions of the small intestine fragments of proteins, lipids and carbohydrates were placed, simulating the digestion and absorption of nutrients by the intestine. In the large intestine only water was distributed (hanging). The molecules were pasted in the tunnel nonwoven fabric with hot glue. Instant glue was used in the stomach, since hot glue does not adhere to cellophane. The hanging molecules and enzymes were fixed with nylon (Figure 10 and 11).

The bacteria were distributed throughout the large intestine, and fixed to the tunnels with strings (Figure 12).

Intestinal villi were simulated with $15 \mathrm{X} 5 \mathrm{~cm}$ orange foam, fixed to tunnels by cable ties. Foam was distributed from the last intestinal enzyme to the end of the small intestine (Figure 13).

Three valves were placed in three places, to simulate the cardia valve (between the esophagus and stomach), pylorus (between stomach and small intestine) and ileocecal (between the small intestine and large intestine). The valves were made of nonwoven fabric (as if they were curtains), the cardia and the pylorus in pink nonwoven fabric and the ileocecal in brown nonwoven fabric (Figure 14). The nonwoven fabric was fixed by cable ties.

Feces were made with newspaper sheets painted with brown colorjet. They were distributed throughout the large intestine so that visitors had to dodge them as they walked through the large intestine (Figure 15).

The anal fold was made by a seamstress using brown nonwoven fabric and elastic band. The elastic placed for anal fold was calculated so that a person could stretch it and go past it. The anal fold was placed at the end of the tunnel (where the large intestine ends) (Figure 16).

The mouth was coated with pink nonwoven fabric from the room door to the entrance of the tunnel. The teeth were made with milk cartons covered with white EVA and placed on pink EVA simulating the gum. Seven upper and lower teeth were made (Figure 17).

The tongue was built with four sheets of red EVA, plus another one on the tip and cut out to imitate the shape of a tongue. The taste buds were made of red EVA in four overlapping disks (Figure 18). 
The food bolus was made with crumpled white EVA and fixed to the floor with hot glue. The uvula was made with a newspaper ball wrapped in pink nonwoven fabric as if it were a bag and fixed on the top of the tunnel which represented the pharynx (Figures 19 and 20).

The mouth molecules were fixed with hot glue.

For the room to be closed at the end of the visitations, the end of the tongue was stuck to the floor with hot glue, and to close the room the lower teeth can be removed and the tongue placed into the room before the door is closed normally.

\section{RESULTS AND DISCUSSION}

After the installation was completed, the ambient room was used so that high school students who had had contact with the digestive process stages could experience the process. Groups of 3 students were formed to visit the room guided by a teacher who explained the whole digestive process.

In the mouth it is important to emphasize the role of teeth in crushing food, being a mechanical digestive process. It is also important to mention the salivary amylase digesting, chemically, carbohydrate food. The group was instructed to go through the uvula, through the pharynx and into the esophagus, which ends in the cardia valve, that controls the passage of food into the stomach cavity (stomach), where it was symbolically demonstrated the acidity due to the presence of Hydrochloric acid molecules which actively assist digestion since they activate the stomach enzymes (pepsin). Students also viewed the enzymatic action of pepsin on protein molecules. In the stomach it was possible to note a different coating representing the stomach mucus, which has the function of protecting the stomach epithelium against its own acid secretion.

Having passed through the stomach, the group of students was directed to the first portion of the small intestine (duodenum), where they were able to observe the secretion of bile salts and the action of enzymes secreted by the pancreas catalyzing reactions with carbohydrates, lipids and proteins. In this part of the tour the student is encouraged to realize that many molecules in the region are already digested (monomeric forms) and ready to be absorbed by the intestinal mucosa. At the next portion of the intestine the emergence of microvilli begins, and students could perceive, with the teacher's guidance, that this is when the nutrients necessary to the body are absorbed. At the end of the small intestine students went past the ileocecal valve, reaching the region of the large intestine where the action of microorganisms in the formation of fecal bolus could be observed. At the end of the digestion process feces are eliminated through the anal folds, from where students could leave the room.

According to Vygostsky's conception, the student associates meanings to symbols (signs), which allows the development of higher psychological processes responsible for voluntary memory and conscious awareness (Nunes, 2011 and Ratner, 1995), thus the objects simulating (symbolizing) certain parts or processes of the digestive system make the student consciously assimilate the stages of the digestive process.

According to Ausubel's theorization on meaningful learning, the ambient room being used to foster understanding of the digestive process is of fundamental importance, since the students learn because they have previous knowledge, and being able to simulate the experience in a concrete manner during their oriented visit to the ambient room can clearly bring the theory closer to their daily lives (Moreira, 2013), thus making understanding and memorization more significant and clear. 
The use of an ambient room as a playful approach activity has proved to be fully capable of assisting the teaching / learning process of the human digestive system, supporting the educational process, adding creativity, commitment and fun, thus improving the students' relation with the institution, teacher, classmates and the science syllabus content.

\section{ACKNOWLEDGMENT}

The authors acknowledge the financial support of the Carlos Chagas Filho Foundation for Research Support of the State of Rio de Janeiro (FAPERJ).

\section{REFERENCES}

BRAGANÇA, B.; FERREIRA, L. A. G.; PONTELO, I. Práticas educativas e ambientes de aprendizagem escolar: relato de três experiências. III Seminário Nacional de Educação Profissional e Tecnológica, CEFET, MG, 2012. Disponível em: <http://www.senept.cefetmg.br/galerias/Arquivos_senept/anais/terca_tema1/ TerxaTema1Artigo17.pdf>. Acesso em: 10 Nov. 2014.

BUSNARDO F.; LOPES A. C. "Os discursos da comunidade disciplinar de ensino de biologia: circulação em múltiplos contextos.” Ciência \& Educação. v.16, 2010.

CONTIN, R. C.; FERREIRA, W. A. Jogos: Instrumentos pedagógicos no Ensino da Matemática. Disponível em <http://www.portaldaeducacao.seduc.mt.gov.br > Acesso em: 11. Nov. 2014.

DE MEIS, L. Ciência, educação e o conflito humano-tecnológico. Science, education and human-technological conflict. 2 ed. São Paulo: Senac. 2002.

FIALHO, N. N. Os jogos pedagógicos como ferramentas de ensino. Disponível em: < http://www.pucpr.br/ eventos/educere/educere2008/anais/pdf/293_114.pdf>. Acesso em: 04 Ago. 2014.

FONTOURA, T. R. Jogo em aula: recurso que permite repensar as relações ensino-aprendizagem. Revista do Professor, v. 19, n. 75, p. 15-9, 2003.

FONTOURA, T. R. O brincar e a educação infantil. Pátio: Educação Infantil, Revista do Professor. v. 1, n. 3, p. 7-9, 2004.

GABOARDI, M. Anatomia e Fisiologia do Sistema Digestório. Disponível em: < $\underline{\text { http://www.granjaviana.med. }}$ br/index.php?option=com_content\&view=article\&id=19\&Itemid=15> Acesso em: 14 Ago. 2013.

GONZALES, F. G.; PALEARI, L. M. O ensino da digestão-nutrição na era das refeições rápidas e do culto ao corpo. Ciência \& Educação, v. 12, n. 1, p. 13-24, 2006.

GUYTON, A. C.; HALL, J. E. Tratado de Fisiologia Médica. 10 ed. Rio de Janeiro: Guanabara Koogan, 2002, 973 p.

HUIZINGA, J. “Homo Ludens”. 4. ed. São Paulo: Perspectiva: 1999.

LIMA, M. B.; LIMA-NETO, P. Construção de modelos para ilustração de estruturas moleculares em aulas de química. Quím. Nova, v. 22, n. 6, São Paulo, 1999. 
MAGALHÃES, E. L. et. al. Ensino por investigação: uma abordagem sobre nutrição e sistema digestório. Disponível em: <http://www.uel.br/ccb/biologiageral/eventos/erebio/painel/T103.pdf> . Acesso em: 08 Ago. 2014.

MARTINS, S. M. A educação brasileira nas últimas décadas: obstáculos e metas dentro e fora da escola. Disponível em: $<$ http://www.unioeste.br/travessias/EDUCACAO/A\%20EDUCACAO\%20BRASILEIRA.pdf $>$. Acesso em: 14 Ago. 2014.

MEGID N. J.; FRACALANZA, H. O livro didático de Ciências: problemas e soluções. Ciência \& Educação, v. 9, n. 2, p. 147-157, 2003.

MIRANDA, S. No Fascínio do jogo, a alegria de aprender. Ciência Hoje, São Paulo, v. 28, p. 64-66, jan. 2001.

MORAES, C. R.; VARELA, S. Motivação do Aluno Durante o Processo de Ensino-Aprendizagem. Revista Eletrônica de Educação. ano I, n. 01, ago. / dez. 2007.

MOREIRA, A. M. Texto de Apoio preparado para a disciplina de pós-graduação Bases Teóricas e Metodológicas para o Ensino Superior, Instituto de Física, UFRGS, 2003 - 2009. Revisado em 2010. Disponível em <moreira.if.ufrgs.br> Acesso: 10. Nov. 2014.

MOREIRA, A. M. Aprendizagem significativa, organizadores prévios, mapas conceituais, diagramas v e unidades de ensino potencialmente significativas. Material de apoio para o curso: Aprendizagem Significativa no Ensino Superior: Teorias e Estratégias Facilitadoras. PUC-PR, 2013.

NEVES, R. A.; DAMIANI, M. F. Vygotsky e as teorias da aprendizagem. UNI revista, vol. 1, n² 2, 2006.

NOVAES, E. C. Vygotsky e a teoria sociointeracionista do desenvolvimento. Disponível em: <http:// edmarciuscarvalho.blogspot.com/2011/08/vygostsky-e-teoria-sociointeracionista.html>. Acesso em: 20 Out. 2014.

NUNES, A. I. B. L.; SILVEIRA, R. N. Psicologia da aprendizagem: processos, teorias, e contextos. 3 ed. Brasília: Liber Livro, 2011.

PELIZZARI, A. et. al. Teoria da aprendizagem significativa segundo Ausubel. Rev. PEC, Curitiba, v.2, n.1, p.37-42, 2002.

RATNER, C. A psicologia sócio-histórica de Vygotsky. Porto Alegre: Artes Médicas, 1995.

ROSAMILHA, N. Psicologia do Jogo e Aprendizagem Infantil. São Paulo: Pioneira, 1979.

SILVA, S.; OLIVEIRA, M. H. P. A contribuição da teoria sócio-interacionista de vigotsky para a educação on line. Revista Sinergia, v. 5, n. 2, p.89-94 , 2004.

STACCIARINI, J.M.R.; ESPERIDIÃO, E. Repensando estratégias de ensino no processo de aprendizagem. Rev. Latino-am. enfermagem, Ribeirão Preto, v. 7, n. 5, p. 59-66, dezembro 1999.

TAVARES, R. Aprendizagem significativa e o ensino de ciências. Ciencia e cognição, v. 13, p 94-100, 2008.

TOSCANI, N. V. et al. Desenvolvimento e análise de jogo educativo para crianças visando à prevenção de doenças parasitológicas. Interface - Comunic. Saúde Educ., v. 11, n. 22, p. 281-94, maio/ago 2007.

VYGOTSKY, L. S. A formação Social da Mente: A formação dos processos psicológicos superiores. 7. ed. São Paulo: Martins Fontes. 2007.

ZANCUL, M. S.; GOMES, P. H. M. A formação de licenciandos em ciências biológicas para trabalhar temas de educação em saúde na escola. REMPEC - Ensino, Saúde e Ambiente, v.4, n1, p.49-61, Abril 2011. 